\title{
Measurement of Indoor Thoron Gas Concentrations Using a Radon-Thoron Discriminative Passive Type Monitor: Nationwide Survey in Japan
}

\author{
Tetsuya Sanada
}

check for updates

Citation: Sanada, T. Measurement of Indoor Thoron Gas Concentrations Using a Radon-Thoron Discriminative Passive Type Monitor: Nationwide Survey in Japan. Int. J. Environ. Res. Public Health 2021, 18, 1299. https://doi.org/10.3390/ijerph18031299

Academic Editor: Paul B. Tchounwou Received: 31 December 2020

Accepted: 29 January 2021

Published: 1 February 202

Publisher's Note: MDPI stays neutral with regard to jurisdictional claims in published maps and institutional affiliations.

Copyright: (C) 2021 by the author. Licensee MDPI, Basel, Switzerland. This article is an open access article distributed under the terms and conditions of the Creative Commons Attribution (CC BY) license (https:// creativecommons.org/licenses/by/ $4.0 /$ )
Department of Radiological Technology, Faculty of Health Sciences, Hokkaido University of Science, Sapporo, Hokkaido 006-8585, Japan; sanada-t@hus.ac.jp

\begin{abstract}
As part of a nationwide survey of thoron $\left({ }^{220} \mathrm{Rn}\right)$ in Japan, the indoor ${ }^{220} \mathrm{Rn}$ gas concentrations in 940 dwellings were measured throughout one year, from 1993 to 1996, using a passive type ${ }^{222} \mathrm{Rn}-{ }^{220} \mathrm{Rn}$ discriminative monitor. The monitor was placed in a bedroom or a living room in each house for four successive three-month periods. The mean annual indoor ${ }^{220} \mathrm{Rn}$ concentration was estimated from the four measurements in each house. The arithmetic mean, the median and the geometric mean for indoor ${ }^{220} \mathrm{Rn}$ concentrations in 899 dwellings were $20.1,9.6$ and $10.0 \mathrm{~Bq} \mathrm{~m}^{-3}$ respectively. The ${ }^{220} \mathrm{Rn}$ concentrations exhibited a log-normal distribution. It was found that the ${ }^{220} \mathrm{Rn}$ concentrations were dependent on the nature of the materials used for wall construction and also on the distance of measurement from the wall. Significant seasonal variations in the ${ }^{220} \mathrm{Rn}$ concentration were not observed. It would seem that the nature of the wall material contributed to the increased indoor ${ }^{220} \mathrm{Rn}$ concentrations.
\end{abstract}

Keywords: thoron; radon; indoor; radioactivity; environment; nationwide survey; SSNTD

\section{Introduction}

Radon $\left({ }^{222} \mathrm{Rn}\right)$, thoron $\left({ }^{220} \mathrm{Rn}\right)$ and their progeny species are large contributors to the annual exposure of an effective dose to the general population. ${ }^{222} \mathrm{Rn}$ and its progeny species contribute about half of the annual effective dose due to natural radiation based on the world mean dose. According to the United Nations Scientific Committee on the Effects of Atomic Radiation [1], the annual effective dose from natural radiation sources has been calculated to be $2.4 \mathrm{mSv}$ as the worldwide average, whereas ${ }^{222} \mathrm{Rn}$ and ${ }^{220} \mathrm{Rn}$ contribute 1.2 and $0.1 \mathrm{mSv}$, respectively. ${ }^{222} \mathrm{Rn}$ and ${ }^{220} \mathrm{Rn}$ are products of the decay chains of natural radionuclides, such as the ${ }^{238} \mathrm{U}$ and ${ }^{232} \mathrm{Th}$ series, and have half-lives of 3.825 days and $55 \mathrm{~s}$, respectively. The ${ }^{220} \mathrm{Rn}$ half-life is very short compared with ${ }^{222} \mathrm{Rn}$. Thus, only a very small amount of ${ }^{220} \mathrm{Rn}$ can enter a room from the outside. It is considered that a ${ }^{220} \mathrm{Rn}$ concentration gradient exists near the mud-based walls and floors in low ventilated houses [2]. Therefore, if a mud mortar wall is present in housing materials which have high concentrations of thorium, ${ }^{220} \mathrm{Rn}$ and its decay products may enter houses and cause potential health problems. In particular, traditional wooden houses with mud mortar walls are a common house type in Japan.

The International Commission on Radiological Protection (ICRP) [3] have issued new dose conversion factors for ${ }^{222} \mathrm{Rn}$ and ${ }^{220} \mathrm{Rn}$ progeny species based on a dosimetric approach in Publication 137. The values specified are 16.8 and $107 \mathrm{nSv}\left(\mathrm{Bq} \mathrm{m}{ }^{-3} \mathrm{~h}\right)^{-1}$, respectively. This means that even small amounts of ${ }^{220} \mathrm{Rn}$ progeny species will cause higher radiation exposure compared to ${ }^{222} \mathrm{Rn}$ [4]. Therefore, interest in ${ }^{220} \mathrm{Rn}$ exposure is growing among the health sciences communities. Recently, a number of ${ }^{220} \mathrm{Rn}$ surveys have been carried out in local regions and nationwide, and the results have been published enabling an evaluation of exposures from ${ }^{220} \mathrm{Rn}$ [5-21]. Also, the need to adopt reliable ${ }^{220} \mathrm{Rn}$ measurement techniques has been argued in several papers [22]. 
An indoor ${ }^{222} \mathrm{Rn}$ survey was conducted on 940 houses nationwide in Japan from 1993 to 1996 using ${ }^{222} \mathrm{Rn}-{ }^{220} \mathrm{Rn}$ discriminative passive type monitors [23]. The passive monitor, developed by Doi and Kobayashi [2], was placed in either a bedroom or a living room where residents spent most of their time. Indoor ${ }^{222} \mathrm{Rn}$ concentrations were determined at 20 dwellings in each prefecture for four successive three-month periods to cover an entire year. In the survey, to eliminate the influence of ${ }^{220} \mathrm{Rn}$ on ${ }^{222} \mathrm{Rn}$ measurement, the ${ }^{220} \mathrm{Rn}$ concentration was performed at the same time for referencing purposes. The ${ }^{222} \mathrm{Rn}$ and ${ }^{220} \mathrm{Rn}$ calibration experiments were performed in a standard radon chamber at the National Radiological Protection Board (Didcot, UK) and using the ${ }^{222} \mathrm{Rn}-{ }^{220} \mathrm{Rn}$ mixed chamber of Waseda University (Tokyo, Japan), respectively. This study is concerned with the results for the indoor ${ }^{220} \mathrm{Rn}$ concentrations using the reference data from the nationwide survey which was conducted to determine the ${ }^{222} \mathrm{Rn}$ concentrations in Japan [23]. Furthermore, the seasonal and regional variations were investigated, and the influence of the type of house structure was examined as mentioned previously. However, this study does not include a dose assessment of ${ }^{220} \mathrm{Rn}$ because the ${ }^{220} \mathrm{Rn}$ concentration varies widely in rooms and it is not easy to measure the activity concentration given the short half-life of the radioisotope [22].

\section{Materials and Methods}

\section{1. ${ }^{220} \mathrm{Rn}$ Monitor and Measurement Periods}

The solid-state nuclear track detector (SSNTD) was developed at the National Institute of Radiological Sciences (Chiba, Japan) as a ${ }^{222} \mathrm{Rn}$ and ${ }^{220} \mathrm{Rn}$ discriminative monitor [2]. The monitor consists of two electroconductive hemispheres and there are two polycarbonate films installed in the center of the two hemispheres. To isolate and separate the progeny species of ${ }^{222} \mathrm{Rn}$ and ${ }^{220} \mathrm{Rn}$, a glass fiber filter is located in the first hemisphere. Therefore, only gaseous ${ }^{222} \mathrm{Rn}$ and ${ }^{220} \mathrm{Rn}$ can pass through the filter and enter the first hemisphere. This monitor has two different diffusion chambers which have relatively large and small ventilation rates. This system has been developed based on the large difference in half-lives of ${ }^{222} \mathrm{Rn}$ and ${ }^{220} \mathrm{Rn}$. After being exposed, the film was first subjected to chemical etching with a mixed solution of $8 \mathrm{~mol} \mathrm{~L}^{-1} \mathrm{KOH}$ and $20 \% \mathrm{C}_{2} \mathrm{H}_{5} \mathrm{OH}$ at $30{ }^{\circ} \mathrm{C}$ for $30 \mathrm{~min}$ [23]. Then the films were electrochemically etched at $800 \mathrm{~V}$ and $2000 \mathrm{~Hz}$ for $2 \mathrm{~h}$. A control film, which was exposed to particles from an ${ }^{241} \mathrm{Am}$ source and which had been etched simultaneously with the sample films, was also prepared to assure the stability of the etching condition. The track density was converted to the average ${ }^{220} \mathrm{Rn}$ concentration by the calibration factor after subtraction of the background track density, i.e., $3.5 \pm 1.8$ tracks cm${ }^{-2}$. In the case of the three month long exposure period, the detection limit (DL) for the concentration of ${ }^{220} \mathrm{Rn}$ was estimated to be $7.4 \mathrm{~Bq} \mathrm{~m}^{-3}(\mathrm{k}=1.65)$, the definition of DL being based on the definition of Currie [24]. Four monitors were used in the survey to determine the mean annual ${ }^{220} \mathrm{Rn}$ concentration. Consequently, the DL for the mean annual ${ }^{220} \mathrm{Rn}$ concentration was estimated to be about $1 / 2$ of DL value specified above. The measurements were carried out for four successive three-month periods to cover a whole year (i.e., January-March, April-June, July-September and October-December) for estimation of the mean annual indoor ${ }^{220} \mathrm{Rn}$ concentration. The survey was carried out for four years (January 1993-June 1996) and conducted in the same manner as reported previously [23].

\section{2. ${ }^{220} \mathrm{Rn}$ Calibration Experiments}

The ${ }^{222} \mathrm{Rn}$ and ${ }^{220} \mathrm{Rn}$ calibration experiments were performed in a standard radon chamber at the National Radiological Protection Board in the UK and at the ${ }^{222} \mathrm{Rn}-{ }^{220} \mathrm{Rn}$ mixed chamber of Waseda University, Tokyo, respectively [25]. ${ }^{220} \mathrm{Rn}$ conversion factor was evaluated to be $0.0098 \pm 0.0016$ (tracks $\mathrm{cm}^{-2}$ per Bq $\mathrm{m}^{-3} \mathrm{~d}$ ). 


\section{Results and Discussion}

\subsection{Distribution of ${ }^{220} \mathrm{Rn}$ Concentration}

The mean annual ${ }^{220} \mathrm{Rn}$ concentrations were obtained for 899 houses, the number of houses monitored being reduced from the original 940 houses as was the case for ${ }^{222} \mathrm{Rn}$ [23]. The annual arithmetic mean, and the median were calculated and values less than the DL $\left(<4 \mathrm{~Bq} \mathrm{~m}^{-3}\right)$ were included in each quarter value. In addition, if a negative value was obtained due to statistical variation as a result of background subtraction, this value was assigned as a zero. The histogram for the mean annual indoor ${ }^{220} \mathrm{Rn}$ concentrations is presented in Figure 1. The mean annual ${ }^{220} \mathrm{Rn}$ concentration was found to vary from $<4$ to $383 \mathrm{~Bq} \mathrm{~m}^{-3}$. The arithmetic mean, the median, the geometric mean and the geometric standard deviation were $20.1 \pm 36.8,9.6,10.0 \mathrm{~Bq} \mathrm{~m}^{-3}$ and 3.2 , respectively. The ${ }^{222} \mathrm{Rn}$ concentrations varied from 3.1 to $208 \mathrm{~Bq} \mathrm{~m}^{-3}$. The arithmetic mean, the median, the geometric mean and the geometric standard deviation were $15.5 \pm 13.5,11.7,12.7 \mathrm{~Bq} \mathrm{~m}^{-3}$ and 1.78, respectively [23]. As a comparison, $\mathrm{Kim}$ et al. reported that the geometric mean for ${ }^{220} \mathrm{Rn}$ concentrations in Korea was $10.7 \mathrm{~Bq} \mathrm{~m}^{-3}$. The log-normal cumulative frequency distribution for the indoor ${ }^{220} \mathrm{Rn}$ concentrations is shown in Figure 2. The ${ }^{220} \mathrm{Rn}$ concentration distribution would appear to be close to a log-normal distribution. The distribution of the mean annual indoor ${ }^{220} \mathrm{Rn}$ concentrations was accepted as a log-normal distribution based on the Kolmogorov-Smirnov test at a significance level of $95 \%$.

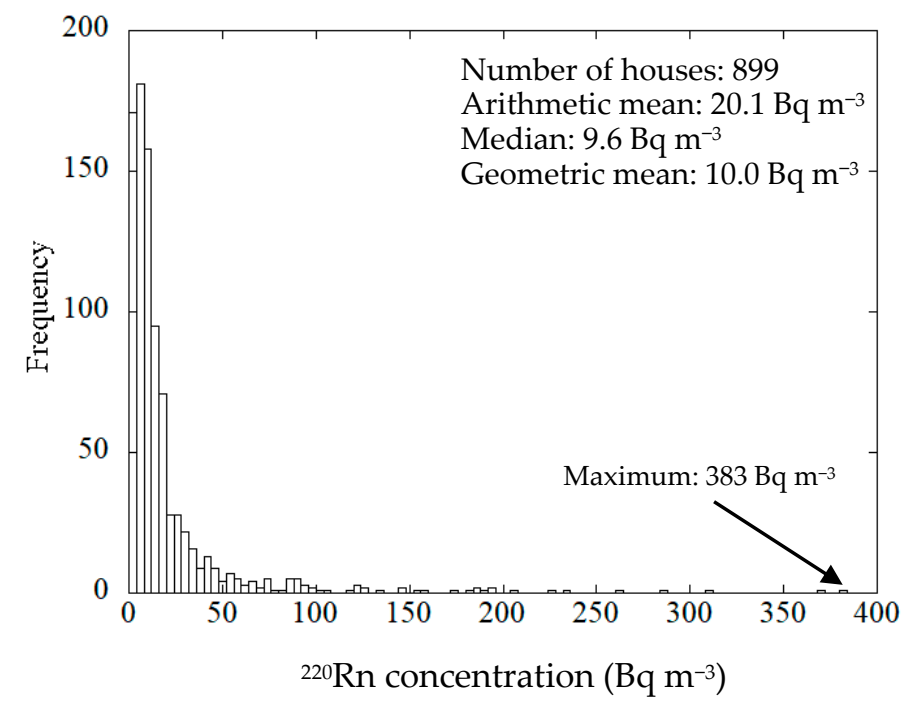

Figure 1. Histogram for indoor ${ }^{220}$ Rn concentrations.

\subsection{Seasonal Variation}

The indoor ${ }^{220} \mathrm{Rn}$ concentration data for each season are presented in Table 1 . Negative values in this dataset were eliminated for calculation of the geometric mean. A significant seasonal variation in the ${ }^{220} \mathrm{Rn}$ concentrations for the four seasons was not found. According to Kim et al. [15] and Stjanovska et al. [16], a temporal pattern in the ${ }^{220} \mathrm{Rn}$ concentration data was observed with values in the winter and spring seasons being higher than those in the summer and autumn. Martinez et al. [17] found that the highest concentrations for Mexico City were in the autumn season and the lowest concentrations were in summer.

In the present study, slight differences were noted in the ${ }^{220} \mathrm{Rn}$ concentrations depending on the periods of exposure. The lowest ${ }^{220} \mathrm{Rn}$ concentrations for all types of houses were observed in the winter season (October-December). However, a different relationship was noted for the ${ }^{222} \mathrm{Rn}$ concentrations, namely, that the ${ }^{222} \mathrm{Rn}$ concentrations tended to be higher in winter compared to the other seasons [23]. This was probably because the residents used domestic heaters to maintain a comfortable room temperature in winter, and 
consequently there would have been increased ventilation rates due to the contribution of convection and/or stack effect in the rooms.

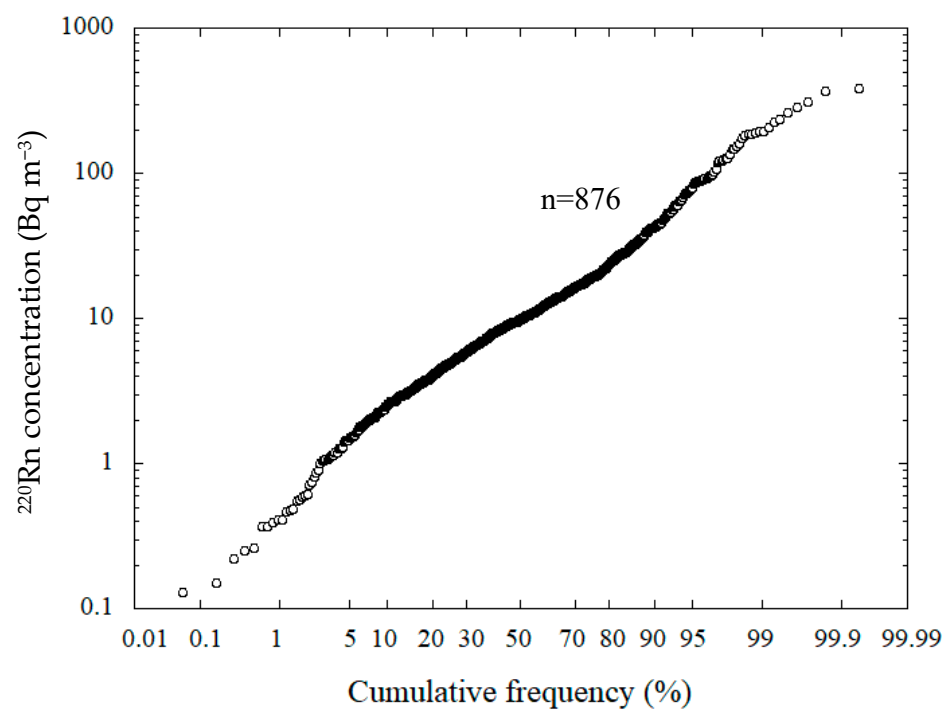

Figure 2. Cumulative frequency distribution for indoor ${ }^{220} \mathrm{Rn}$ concentrations. This figure has been prepared using the mean annual ${ }^{220} \mathrm{Rn}$ concentrations in excess of zero $\mathrm{Bq} \mathrm{m}^{-3}$.

Table 1. ${ }^{220} \mathrm{Rn}$ concentrations measured in the different seasons.

\begin{tabular}{cccccc}
\hline \multirow{2}{*}{ Measurement Period } & $\begin{array}{c}\text { Number of } \\
\text { Houses }\end{array}$ & AM & SD & $\begin{array}{c}{ }^{\mathbf{2 2 0}} \mathbf{R n}\left(\mathbf{B q ~ m}^{-3} \text { ) }\right. \\
\text { (Number of Houses) }\end{array}$ \\
\cline { 3 - 6 } & & 18.9 & 40.0 & $14.6(576)$ & GSD \\
\hline January-March & 899 & 22.8 & 39.2 & $14.4(733)$ & 3.5 \\
April-June & & 21.9 & 42.3 & $14.0(713)$ & 3.3 \\
July-September & & 16.6 & 41.0 & $13.0(492)$ & 3.9 \\
October-December & &
\end{tabular}

AM: Arithmetic mean; SD: Standard deviation; GM: Geometric mean; GSD: Geometric standard deviation (dimensionless).

The variation of the ${ }^{220} \mathrm{Rn}$ concentration in the rooms was slightly different from that of ${ }^{222} \mathrm{Rn}$, which may reflect the differences in the half-lives and sources of ${ }^{220} \mathrm{Rn}$, despite the fact that there were large fluctuations in the standard deviations for the seasonal variations of ${ }^{220} \mathrm{Rn}$ concentrations. The reason why the indoor ${ }^{220} \mathrm{Rn}$ concentrations did not display a variation similar to ${ }^{222} \mathrm{Rn}$ is unclear at this time.

\subsection{Nature of Housing}

Indoor ${ }^{220} \mathrm{Rn}$ concentrations were categorized in terms of the structural features of the housing. The annual mean, the standard deviation, and the geometric mean for the indoor ${ }^{220} \mathrm{Rn}$ concentrations together with number of houses monitored are given in Table 2 . The arithmetic and geometric mean concentrations for wooden and concrete-based houses have higher values than those of other structures, although there were large fluctuations in the data. The maximum value was found for a wooden house with a mud wall, the highest ${ }^{220} \mathrm{Rn}$ concentration being $383 \mathrm{~Bq} \mathrm{~m}^{-3}$. The cause of the high ${ }^{220} \mathrm{Rn}$ concentration of wooden houses is that they have relatively high ratio of the mud wall in comparison to other house structure types. Table 3 lists the ratio of the mud wall in each housing type. Accordingly, the ${ }^{220} \mathrm{Rn}$ concentrations in wooden houses are higher than those for other housing types. 
Table 2. The mean annual ${ }^{220} \mathrm{Rn}$ concentration for each type of house.

\begin{tabular}{ccccc}
\hline \multirow{2}{*}{ Structure } & $\begin{array}{c}\text { Number of } \\
\text { Houses }\end{array}$ & \multicolumn{3}{c}{${ }^{\mathbf{2 2 0}} \mathbf{R n} \mathbf{( B q ~ \mathbf { ~ m } ^ { - 3 } \mathbf { ) }}$} \\
\cline { 3 - 5 } & & $\mathbf{A M}$ & $\mathbf{S D}$ & $\mathbf{G M}$ \\
\hline Wooden & 597 & 23.1 & 40.7 & 10.8 \\
Concrete & 182 & 16.3 & 32.5 & 9.6 \\
Steel frame & 90 & 8.6 & 8.9 & 6.1 \\
Concrete block & 16 & 21.8 & 25.6 & 13.8 \\
Prefabricated & 6 & 3.4 & 2.6 & 2.7 \\
\hline
\end{tabular}

AM: Arithmetic mean; SD: Standard deviation; GM: Geometric mean.

Table 3. Ratio of mud wall in each structure type.

\begin{tabular}{cccc}
\hline Structure Type & $\begin{array}{c}\text { Total Number of } \\
\text { Houses }\end{array}$ & $\begin{array}{c}\text { Number of Mud } \\
\text { Wall Houses }\end{array}$ & $\begin{array}{c}\text { Ratio of Mud Wall } \\
\text { in the House (\%) }\end{array}$ \\
\hline Wooden & 597 & 190 & 31.8 \\
Concrete & 182 & 3 & 1.6 \\
Steel frame & 90 & 0 & 0 \\
Concrete block & 16 & 1 & 6.3 \\
Prefabricated & 6 & 0 & 0 \\
\hline
\end{tabular}

With respect to the ${ }^{220} \mathrm{Rn}$ concentrations by region, the overall ratios for wooden houses with mud walls in the Hokkaido-Tohoku, Kanto and Kyushu-Okinawa areas are lower than for those in other areas of Japan. Therefore, the ${ }^{220} \mathrm{Rn}$ concentrations in these former areas also tends to be lower than the values found in the other areas.

\subsection{Dependency of ${ }^{220} R n$ Concentration on Wall Structure and Distance from Wall}

The present survey on ${ }^{220} \mathrm{Rn}$ concentrations considered four categories of material which were used for wall construction in the houses. The mean annual ${ }^{220} \mathrm{Rn}$ concentrations obtained by passive measurement for the different wall materials in the houses are presented in Figure 3. Inspection of the results (Figure 3) reveals that high ${ }^{220} \mathrm{Rn}$ concentrations occurred for houses with mud walls, and the values decreased gradually with distance from the surface of the wall as shown in Figure 4. Yonehara et al. reported similar behavior for ${ }^{220} \mathrm{Rn}$ concentrations at locations near the wall surfaces in Japanese dwellings [26].

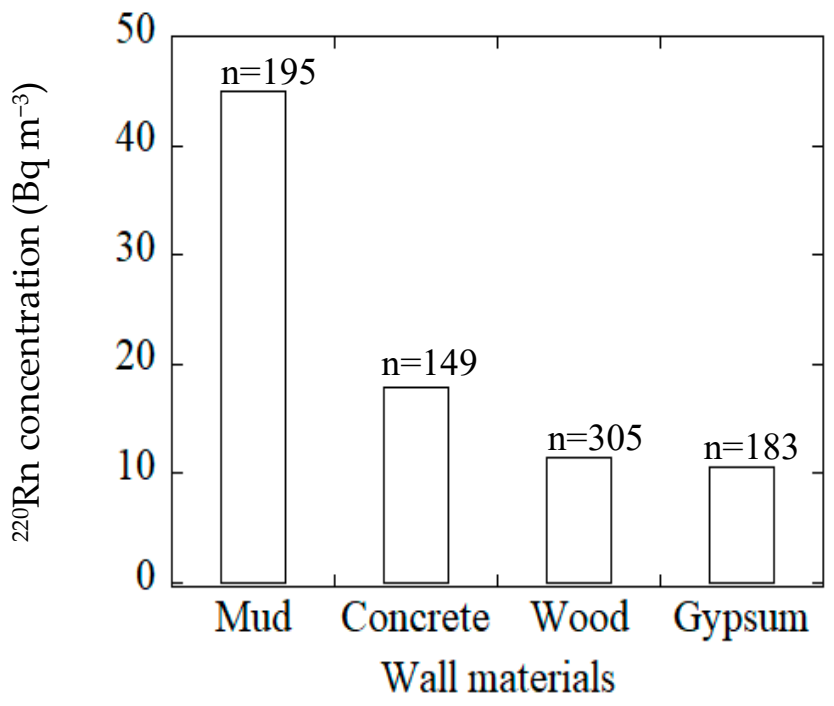

Figure 3. ${ }^{220} \mathrm{Rn}$ concentrations for various wall materials. 


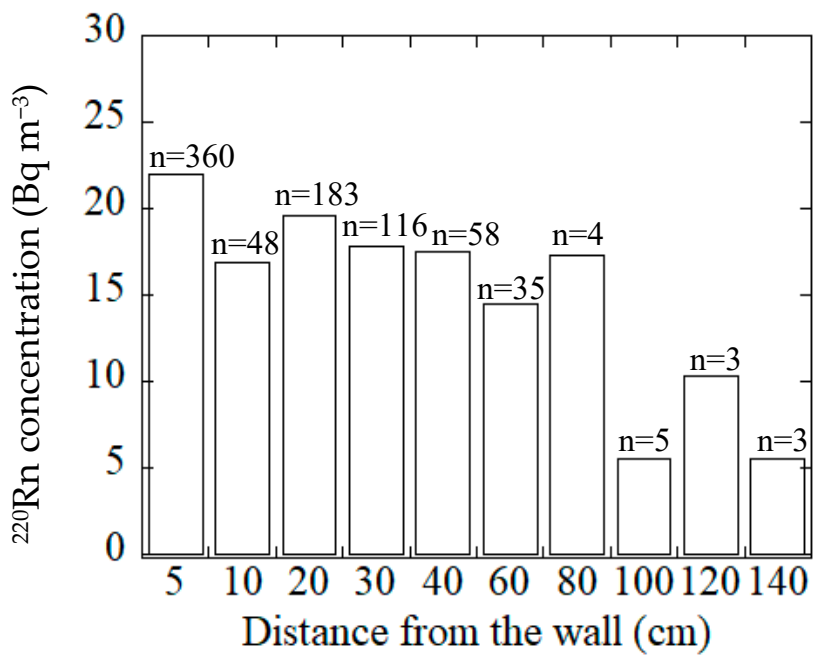

Figure 4. ${ }^{220} \mathrm{Rn}$ concentrations at different distances from the wall surface for all wall materials.

\section{5. ${ }^{220} \mathrm{Rn}$ and ${ }^{222} \mathrm{Rn}$ Correlation}

The correlation between the indoor ${ }^{220} \mathrm{Rn}$ and ${ }^{222} \mathrm{Rn}$ concentrations was investigated. The relationship between the ${ }^{220} \mathrm{Rn}$ and the ${ }^{222} \mathrm{Rn}$ concentrations is illustrated in Figure 5 . The concentration distributions for both radioisotopes follow approximately a log-normal distribution. Consequently, both datasets were calculated after taking the logarithms of the respective data. The linear regression analysis shows a weak positive correlation $(R=0.25)$. The ratio for the concentrations of ${ }^{220} \mathrm{Rn} /{ }^{222} \mathrm{Rn}$ ranged from 0.007 to 40.3 and reveal a log-normal plot. The arithmetic mean for ${ }^{220} \mathrm{Rn} /{ }^{222} \mathrm{Rn}$ was 1.64 and geometric mean was 0.78 .

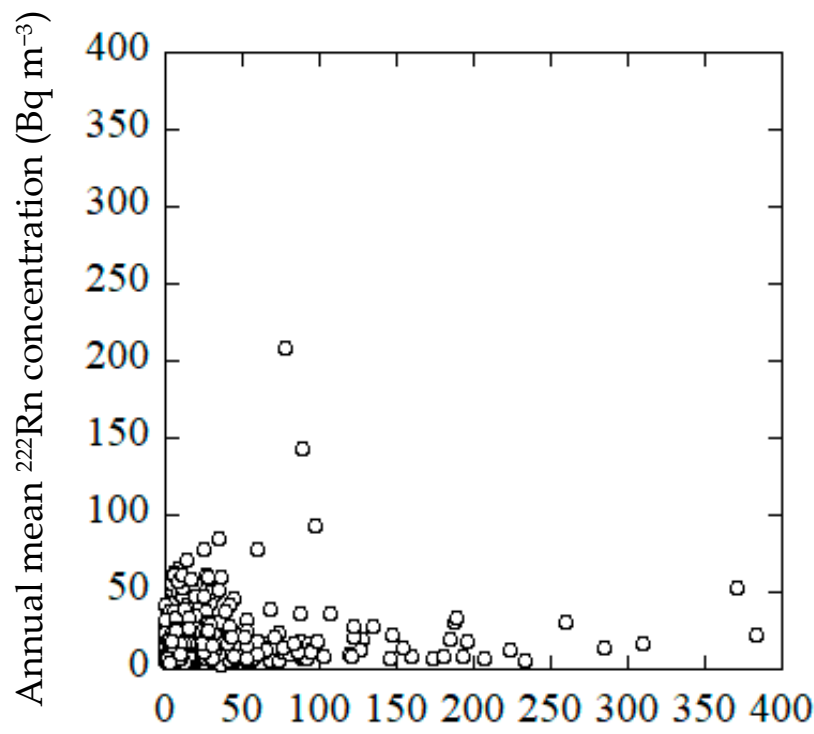

\section{Annual mean ${ }^{220} \mathrm{Rn}$ concentration $\left(\mathrm{Bq} \mathrm{m}^{-3}\right)$}

Figure 5. Correlation between the mean annual concentrations of ${ }^{220} \mathrm{Rn}$ and ${ }^{222} \mathrm{Rn}$.

\section{Conclusions}

The mean annual indoor ${ }^{220} \mathrm{Rn}$ concentrations were measured in 899 houses using a passive ${ }^{222} \mathrm{Rn}-{ }^{220} \mathrm{Rn}$ discriminative monitor. The arithmetic mean, the median and the geometric mean were $20.1,9.6$ and $10.0 \mathrm{~Bq} \mathrm{~m}^{-3}$, respectively. The ${ }^{220} \mathrm{Rn}$ concentration plot exhibited a log-normal distribution. The maximum ${ }^{220} \mathrm{Rn}$ concentration found in the present survey was $383 \mathrm{~Bq} \mathrm{~m}^{-3}$ for a wooden house with mud walls. The survey 
data for the indoor ${ }^{220} \mathrm{Rn}$ concentrations in Japan did not exhibit a significant seasonal variation. There was a marked difference in the ${ }^{220} \mathrm{Rn}$ concentration depending on the nature of the house structure. Relatively higher concentrations of ${ }^{220} \mathrm{Rn}$ were found in wooden and concrete block houses compared to other housing types. In general, the ${ }^{220} \mathrm{Rn}$ concentrations in traditional wooden houses with mud walls tended to be higher than those for houses with different wall types. Further, it was demonstrated that the ${ }^{220} \mathrm{Rn}$ concentrations decreased with distance of measurement from the wall.

Funding: This research was carried out in collaboration with 47 prefectural institutes under the auspices of the former Science and Technology Agency of Japan.

Institutional Review Board Statement: Not applicable for studies not involving humans or animals.

Informed Consent Statement: Not applicable for studies not involving humans.

Data Availability Statement: The data presented in this study are available on request from the corresponding author.

Conflicts of Interest: The author declares no conflict of interest.

\section{References}

1. United Nations Scientific Committee on the Effects of Atomic Radiation. Volume I: Annex B Exposures of the Public and Workers from Various Sources of Radiation. In UNSCEAR 2008 Report, Sources and Effects of Ionizing Radiation; UNSCEAR: New York, NY, USA, 2010.

2. Doi, M.; Kobayashi, S. The passive radon-thoron discriminative dosimeter for practical use. Hoken Butsuri. 1994, $29,155-166$. [CrossRef]

3. International Commission on Radiological Protection. Occupational intakes of radionuclides: Part 3. In Annals of the ICRP 46 (3/4); ICRP Publication 137: London, UK, 2017.

4. Tokonami, S. Characteristic of Thoron $\left({ }^{220} \mathrm{Rn}\right)$ and its progeny in the indoor environment. Int. J. Environ. Res. Public Health 2020, 17, 8769. [CrossRef]

5. $\quad$ Bineng, G.S.; Saïdou, S.T.; Hosoda, M.; Siaka, Y.F.; Issa, H.; Suzuki, T.; Kudo, H.; Bouba, O. The importance of direct progeny measurements for correct estimation of effective dose due to radon and thoron. Front. Public Health 2020, 8, 17. [CrossRef] [PubMed]

6. Chen, J.; Moir, D.; Sorimachi, A.; Janik, M.; Tokonami, S. Determination of thoron equilibrium factor from simultaneous long-term thoron and its progeny measurements. Radiat. Prot. Dosim. 2012, 149, 155-158. [CrossRef]

7. Chen, J.; Bergman, L.; Falcomer, R.; Whyte, J. Results of simultaneous radon and thoron measurements in 33 metropolitan areas of Canada. Radiat. Prot. Dosim. 2015, 163, 210-216. [CrossRef] [PubMed]

8. Kudo, H.; Tokonami, S.; Omori, Y.; Ishikawa, T.; Iwaoka, K.; Sahoo, S.K.; Akata, N.; Hosoda, M.; Pornnumpa, C.; Sun, Q.; et al. Comparative dosimetry for radon and thoron in high background radiation areas in China. Radiat. Prot. Dosim. 2015, 167, 155-159. [CrossRef] [PubMed]

9. Shang, B.; Tschiersch, J.; Cui, H.; Xia, Y. Radon survey in dwellings of Gansu, China: The influence of thoron and an attempt for correction. Radiat. Environ. Biophys. 2008, 47, 367-373. [CrossRef]

10. Tokonami, S.; Sun, Q.; Akiba, S.; Zhuo, W.; Furukawa, M.; Ishikawa, T.; Hou, C.; Zhang, S.; Narazaki, Y.; Ohji, B.; et al. Radon and thoron exposures for cave residents in Shanxi and Shaanxi Provinces. Radiat. Res. 2004, 162, 390-396. [CrossRef]

11. Kovacs, T. Thoron measurements in Hungary. Radiat. Prot. Dosim. 2010, 141, 328-334. [CrossRef]

12. Omori, Y.; Tokonami, S.; Sahoo, S.K.; Ishikawa, T.; Sorimachi, A.; Hosoda, M.; Kudo, H.; Pornnumpa, C.; Nair, R.R.K.; Jayalekshmi, P.A.; et al. Radiation dose due to radon and thoron progeny inhalation in high-level natural radiation areas of Kerala, India. J. Radiol. Prot. 2017, 37, 111-126. [CrossRef]

13. Mc Laughlin, J.P.; Murray, M.; Currivan, L.; Pollard, D.; Smith, V.; Tokonami, S.; Sorimachi, A.; Janik, M. Thoron and its airborne progeny in Irish dwellings. In Proceedings of the Third European IRPA Congress, Helsinki, Finland, 14-18 June 2010; pp. 2607-2612.

14. Nyambura, C.; Tokonami, S.; Hashim, N.O.; Chege, M.W.; Suzuki, T.; Hosoda, M. Annual effective dose assessment due to radon and thoron progenies in dwellings of Kilimanbogo, Kenya. Radiat. Prot. Dosim. 2019, 184, 430-434. [CrossRef] [PubMed]

15. Kim, C.K.; Kim, Y.J.; Lee, H.Y.; Chang, B.U.; Tokonami, S. ${ }^{220} \mathrm{Rn}$ and its progeny in dwellings of Korea. Radiat. Meas. 2007, 42, 1409-1414. [CrossRef]

16. Stojanovska, Z.; Bossew, P.; Tokonami, S.; Zunic, Z.; Bochicchio, F.; Boev, B.; Ristova, M.; Januseski, J. National survey of indoor thoron concentration in FYR of Macedonia (continental Europe-Balkan region). Radiat. Meas. 2013, 49, 57-66. [CrossRef]

17. Martinez, T.; Navarrete, M.; Gonzalez, P.; Ramirez, A. Variation in indoor thoron levels in Mexico City dwellings. Radiat. Prot. Dosim. 2004, 111, 111-113. [CrossRef] 
18. Smetsers, R.C.G.M.; Blaauboer, R.O.; Dekkers, F.; Slaper, H. Radon and thoron progeny in Dutch dwellings. Radiat. Prot. Dosim. 2018, 181, 11-14. [CrossRef]

19. Vaupotic, J.; Kavasi, N. Preliminary study of thoron and radon levels in various indoor environments in Slovenia. Radiat. Prot. Dosim. 2010, 141, 383-385. [CrossRef]

20. Saputra, M.A.; Nugraha, E.D.; Purwanti, T.; Arifianto, R.; Laksmana, R.I.; Hutabarat, R.P.; Hosoda, M.; Tokonami, S. Exposures from radon, thoron, and thoron progeny in high background radiation area in Takandeang, Mamuju, Indonesia. Nukleonika 2020, 65, 89-94. [CrossRef]

21. Wang, Z.; Lubin, J.; Wang, L.; Zhang, S.; Boice, J.; Cui, H.; Zhang, S.; Conrath, S.; Xia, Y.; Shang, B.; et al. Residential radon and lung cancer risk in a high-exposure area of Gansu Province, China. Am. J. Epidemiol. 2002, 155, 554-564. [CrossRef]

22. Hosoda, M.; Kudo, H.; Iwaoka, K.; Yamada, R.; Suzuki, T.; Tamakuma, Y.; Tokonami, S. Characteristic of thoron ( $\left.{ }^{220} \mathrm{Rn}\right)$ in environment. Appl. Radiat. Isot. 2017, 120,7-10. [CrossRef]

23. Sanada, T.; Fujimoto, K.; Miyano, K.; Doi, M.; Tokonami, S.; Uesugi, M.; Takata, Y. Measurement of nationwide indoor Rn concentration in Japan. J. Environ. Radioact. 1999, 129-137. [CrossRef]

24. Currie, L.A. Limits for qualitative detection and quantitative determination. Anal. Chem. 1968, 40, 586-593. [CrossRef]

25. Kurosawa, R.; Tokonami, S.; Kamota, F. On the convenient test chamber for calibration of passive integrating radon-thoron monitor, environmental radon. In Proceedings of the '91 Radon Symposium, Kumatori, Japan, 8-10 August 1992; pp. 464-475.

26. Yonehara, H.; Tokonami, S.; Zhuo, W.; Ishikawa, T.; Fukutsu, K.; Yamada, Y. Thoron in the living environments of Japan. Int. Congr. Ser. 2005, 1276, 58-61. [CrossRef] 